\title{
Gambaran Hasil Pemeriksaan Monofilamen pada Pasien Diabetes Melitus (DM) yang Berkunjung ke Poliklinik Penyakit Dalam RSUD Arifin Achmad Provinsi Riau
}

\author{
Viona Ayu Safitri ${ }^{1 *}$, Dani Rosdiana ${ }^{2}$, Riezky Valentina Astari ${ }^{3}$
}

\begin{abstract}
Diabetes mellitus in increasing at an alarming rate and has become a global challenge. Diabetes mellitus type 2 is a group of metabolic diseases characterized by hyperglycemia resulting from defects in insulin secretion, insulin action or both. One of the most complications of diabetes is diabetic neuropathy. Diabetic neuropathy refers to damage of motor nerves, sensory, and autonomic system. The aim of this study is to identify patients at risk for diabetic neuropathy with monofilament examination in internist polyclinic Arifin Achmad General Hospital from May to July 2017. Monofilament is an inexpensive, practical tool in everyday use and can be used in early detection of sensation loss in the foot to prevent diabetic ulcer. This study is descriptive research with direct examination of patient diabetes type 2 . There were 73 samples that fulfilled the inclusion criteria. Profile patients with diabetes in the polyclinic are female more than male is $60,3 \%$. The age group 56-65 years is the most age group of DM patients in the polyclinic is $52.1 \%$. Duration of diabetes is $5-10$ years $(52.1 \%)$. The results of monofilament examination in patients with type 2 DM are score $0-3$ as many as 19 people (26\%), score of 3.5-5 as many as 27 people (37\%), and score $>5,5$ as many as 27 people $(37 \%)$.
\end{abstract}

Keywords: Diabetes Mellitus (DM), neuropathy, monofilament, diabetic ulcers, monofilament examination

Menurut International Diabetes Federation (IDF), pada tahun 2015 ada 415 juta orang di dunia dengan diabetes dan diperkirakan pada tahun 2040 akan meningkat menjadi 642 juta orang. ${ }^{1}$ Penyakit DM jika dikelola dengan baik dapat menurunkan risiko komplikasi pada berbagai sistem tubuh. Komplikasi DM dapat akut atau kronik. Komplikasi akut seperti hipoglikemi dan ketoasidosis. Sedangkan untuk komplikasi kronik meliputi gangguan makrovaskuler dan mikrovaskuler. Komplikasi makrovaskuler dapat berupa penyakit arteri koroner, Sementara gangguan mikrovaskuler seperti retinopati diabetes, nefropati diabetes serta neuropati diabetes. ${ }^{2}$

Gejala-gejala neuropati seperti rasa kebas, rasa terbakar, rasa tertusuk dan lainnya merupakan masalah yang sering dikeluhkan tapi jarang

\footnotetext{
* Korespondensi email : vionaayusafitri@gmail.com

1 Fakultas Kedokteran Universitas Riau

2 KJF Ilmu Penyakit Dalam Fakultas Kedokteran Univrsitas Riau/ RSUD Arifin Achmad Provinsi Riau

3 KJF Saraf Fakultas Kedokteran Univrsitas Riau/ RSUD Arifin Achmad Provinsi Riau
}

diperhatikan. Neuropati jarang diobati oleh pasien karena tidak mengetahui gejalanya dan masalah ini dapat mengganggu kualitas hidup pasien. Jambart dkk melaporkan bahwa dari total 4097 pasien, 90,6\% menderita DM tipe 2. Kemudian diantara 90,6\% tersebut, yang memiliki komplikasi neuropati diabetik sebesar 19,4\%, selanjutnya diikuti oleh komplikasi DM yang lain seperti disfungsi ereksi sebesar 17,5\% dan retinopati diabetik sebesar $16,8 \%{ }^{3}$ Hal ini menyebabkan masalah neuropati menjadi perhatian bagi semua pihak.

Neuropati dapat menyebabkan gangguan saraf motorik, sensorik dan otonom. Gangguan motorik yang terjadi bisa menyebabkan atrofi pada otot, deformitas kaki, perubahan biomekanika kaki dan distribusi tekanan kaki akan terganggu sehingga dapat meningkatkan kejadian ulkus. Selain itu, gangguan sensorik yang terjadi disadari oleh pasien saat mengeluhkan kaki kehilangan sensasi atau terasa kebas. Rasa kebas yang dirasakan menyebabkan trauma yang dialami pada pasien DM sering tidak diketahui. Gangguan otonom yang disebabkan oleh neuropati menyebabkan bagian kaki mengalami 
penurunan ekskresi keringat sehingga kulit kaki menjadi kering dan mudah terbentuk fisura. Ketika terjadi trauma kecil pada kaki yang sudah mengalami neuropati dapat meningkatkan risiko terjadinya ulkus diabetikum. ${ }^{4}$

Penelitian Boulton tahun 2004 menyatakan bahwa pasien DM dengan neuropati dapat meningkatkan risiko terjadinya ulkus diabetikum tujuh kali dibandingkan dengan pasien DM tidak neuropati. ${ }^{5}$ Pada penelitian Nyamu PN dkk tahun 2003 terhadap 1788 pasien DM yang telah diskrining, ditemukan memiliki ulkus pada kaki sebanyak 82 pasien (4,6\%). Jenis ulkus yang paling sering muncul adalah neuropati $47,5 \% .^{6}$

Pada neuropati diabetik penting dilakukan skrining dan diagnosis dini untuk menurunkan risiko ulkus diabetikum. Oleh karena itu dibutuhkan alat yang sederhana, murah dan sensitif untuk mendeteksi polineuropati. Ada metode yang dapat digunakan dalam mendeteksi polineuropati seperti Clinical Neurological Examination (CNE) dan monofilamen. Berdasarkan penelitian Bambang di rumah sakit Kariadi Semarang mengenai nilai diagnostik monofilamen $10 \mathrm{~g}$ dan skor CNE pada polineuropati diabetik tahun 2003 didapatkan bahwa monofilamen $10 \mathrm{~g}$ dan CNE memiliki sensitifitas yang cukup baik $(80,6 \%)$ untuk diagnosis polineuropati diabetik dalam penggunaan klinis sehari-hari dengan acuan pemeriksaan Elekromiografi (EMG). ${ }^{7}$ Metode pemeriksaan yang akan dilakukan dalam penelitian ini adalah pemeriksaan monofilamen dan dilakukan oleh peneliti langsung yang telah dilatih oleh dokter spesialis penyakit dalam. Pemeriksaan ini memiliki beberapa kelebihan selain dari sensitifitas yang cukup baik, tes ini juga mudah untuk dilakukan dan biayanya tidak mahal.

Pemeriksaan dengan menggunakan monofilamen terhadap pasien DM jarang dilakukan atau belum menjadi pemeriksaan rutin di RSUD Arifin Achmad Provinsi Riau. Hal ini membuat peneliti tertarik untuk melakukan penelitian yang berjudul gambaran hasil pemeriksaan monofilamen pada pasien DM di poli klinik penyakit dalam RSUD Arifin Achmad Provinsi Riau.

\section{METODE}

Penelitian ini merupakan penelitian deskriptif yaitu untuk mengetahui gambaran hasil pemeriksaan monofilamen pada pasien DM tipe 2 yang berkunjung ke poliklinik penyakit dalam RSUD Arifin Achmad Provinsi Riau. Populasi penelitian ini adalah seluruh pasien DM tipe 2 di poliklinik penyakt dalam RSUD Arifin Achmad Provinsi Riau periode Mei-Juli 2017. Sampel penelitian ini adalah seluruh populasi penelitian (total sampling).

Data pada penelitian ini merupakan data primer yang diperoleh dari pengukuran langsung, dan wawancara pada pasien DM di poliklinik penyakit dalam RSUD Arifin Achmad Provinsi Riau periode Mei-Juli 2017.

Pada penelitian ini variabel yang digunakan adalah jenis kelamin, usia, lama riwayat DM dan pemeriksaan monofilamen.

\section{HASIL}

Karakteristik pasien Diabetes Melitus (DM) yang berkunjung ke poliklinik penyakit dalam RSUD Arifin Achmad Provinsi Riau

Pasien DM yang datang berkunjung ke poli klinik penyakit dalam RSUD Arifin Achmad periode Mei-Juli 2017 memiliki karakteristik yaitu jumlah pasien perempuan lebih banyak dari pada pasien lakilaki sebanyak 44 (60,3\%), kelompok usia terbanyak adalah 56-65 tahun sebanyak 38 orang $(52,1 \%)$, kelompok lama riwayat DM terbanyak adalah 5-10 tahun yaitu sebanyak 38 orang $(52,1 \%)$. Data selengkapnya mengenai karakteristik pasien dapat dilihat di Tabel 1. 
Tabel 1. Karakteristik pasien Diabetes Melitus (DM) yang berkunjung ke poli penyakit dalam RSUD Arifin Achmad Provinsi Riau

\begin{tabular}{cc}
\hline \multicolumn{1}{c}{ Karakteristik } & Jumlah (\%) \\
\hline Jenis kelamin & $29(39,7)$ \\
$\bullet \quad$ Laki-laki & $44(60,3)$ \\
Kelompok usia & \\
$\bullet \quad<45$ tahun & $2(2,7)$ \\
$\bullet \quad 46-55$ tahun & $12(16,4)$ \\
$\bullet \quad 56-65$ tahun & $38(52,1)$ \\
$\bullet \quad>65$ tahun & $21(28,8)$ \\
Lama riwayat Diabetes & \\
Melitus (DM) & $14(19,2)$ \\
$\bullet \quad<5$ tahun & $38(52,1)$ \\
$\bullet \quad 5-10$ tahun & $21(28,8)$ \\
\hline$\quad>10$ tahun & \\
\hline
\end{tabular}

Hasil pemeriksaan monofilamen pada pasien Diabetes Melitus (DM) di poli klinik penyakit dalam RSUD Arifin Achmad Provinsi Riau

Pada penelitian ini dilakukan pemeriksaan monofilamen pada 73 pasien DM tipe 2 yang datang berkunjung ke poli penyakit dalam RSUD Arifin Achmad Provinsi Riau pada bulan Mei-Juli 2017. Pemeriksaan monofilamen dilakukan dengan tujuan untuk mendeteksi dini kehilangan sensasi untuk menurunkan risiko komplikasi dari DM khususnya komplikasi neuropati agar tidak menjadi lebih berat. Pada penelitian ini ditemukan bahwa kelompok pasien DM dengan skor 0-3 (The presence of neuropathy is likely) sebanyak 19 orang (26\%), kelompok pasien dengan skor 3,5-5 (The risk of new onset neuropathy in the next four years is high) yaitu 27 orang (37\%), dan kelompok pasien dengan skor $>5,5$ (Low risk of neuropathy onset in the next four years) sebanyak 27 orang (37\%). Data selengkapnya mengenai hasil pemeriksaan monofilamen dapat dilihat pada Tabel 2.

Tabel 2. Hasil pemeriksaan monofilamen pada pasien Diabetes Melitus (DM) di poli klinik penyakit dalam RSUD Arifin Achmad Provinsi Riau

Hasil pemeriksaan $\quad$ Jumlah pasien (\%)

$0-3$

The presence of neuropathy is likely

$19(26)$

$$
3,5-5
$$

The risk of new onset neuropathy in

the next four years is high

$$
>5,5
$$

Low risk of neuropathy onset in the next four years 


\section{PEMBAHASAN}

\section{Karakteristik pasien Diabetes Melitus (DM) yang berkunjung ke poli klinik penyakit dalam RSUD Arifin Achmad Provinsi Riau}

Berdasarkan hasil penelitian diketahui bahwa jenis kelamin perempuan lebih banyak terkena DM daripada laki-laki. Hal ini menunjukkan bahwa perempuan memiliki risiko untuk terkena DM lebih besar daripada laki-laki. Hal ini sesuai dengan penelitian Irawan tahun 2010 menunjukkan hasil jika prevalensi DM tipe 2 pada perempuan lebih tinggi (6,71\%) dibandingkan dengan laki-laki $(5,11 \%)$. Perempuan lebih berisiko untuk terkena DM karena secara fisik perempuan mempunyai peluang yang besar dalam peningkatan indeks masa tubuh. Adanya siklus bulanan, dan pasca menopause menyebabkan distribusi lemak tubuh pada perempuan mudah terakumulasi akibat proses hormonal sehingga perempuan berisiko menderita DM tipe $2 .{ }^{8} \mathrm{Namun}$ hasil penelitian ini sedikit berbeda dengan penelitian Tami Endriani Pardede tahun 2016 berdasarkan jenis kelamin hasilnya yaitu jenis kelamin laki-laki 27 orang $(52,9 \%)$ dan perempuan 24 orang $(47,1 \%){ }^{9}$

Berdasarkan hasil penelitian kelompok usia terbanyak berada pada rentang 56-65 tahun dengan jumlah 38 orang $(52,1 \%)$. Menurut Departemen Kesehatan tahun 2009, usia 56-65 merupakan usia lansia. Risiko diabetes meningkat seiring dengan peningkatan usia, khususnya usia lebih dari 40 tahun. Pada usia tersebut mulai terjadi peningkatan intoleransi glukosa oleh tubuh dan proses penuaan juga dapat menyebabkan penurunan dari kemampuan sel â pankreas dalam memproduksi insulin. ${ }^{10}$ Hasil penelitian ini sejalan dengan penelitian Tami tahun 2016 yang menunjukkan bahwa kelompok usia 45-65 tahun adalah kelompok usia terbanyak menderita DM $(70,6 \%) .{ }^{9}$ Penelitian lain yang mendukung hasil ini adalah penelitian Zahtamal dkk tahun 2007 yang menunjukkan bahwa kelompok usia $>45$ tahun adalah kelompok usia terbanyak menderita diabetes mellitus $(88,61 \%)$ daripada kelompok usia dibawahnya. Hal tersebut dikarenakan DM merupakan penyakit degeneratif karena terdapat gangguan pada metabolisme karbohidrat, lemak, dan protein yang ditandai dengan hiperglikemia, sehingga kasus DM akan meningkat seiring dengan bertambahnya usia. ${ }^{11}$
Pada penelitian ini didapatkan hasil bahwa lama riwayat DM paling banyak berada direntang 5-10 tahun sebanyak 38 orang $(52,1 \%)$. Hal ini menunjukkan bahwa semakin lama seseorang menderita DM maka semakin besar risiko untuk menderita komplikasi diabetes. International Diabetes Federation (IDF) 2011 dan Yuliani dkk menyebutkan bahwa pasien DM yang mengalami diabetes selama 5-10 tahun akan berisiko untuk terkena komplikasi makroangiopati dan 5-15 tahun akan menderita komplikasi mikroangiopati. ${ }^{12,13}$ Keadaan ini membuat kualitas hidup pasien diabetes melitus semakin menurun. Secara epidemiologi dikatakan bahwa diabetes sering tidak terdeteksi atau mulai terjadinya diabetes adalah 7 tahun sebelum diagnosis ditegakkan, sehingga angka morbiditas dan mortalitas dini terjadi pada kasus tidak terdeteksi. ${ }^{14}$ Namun pada penelitian Rosyntha tahun 2016 menunjukkan hasil yang berbeda bahwa neuropati diabetik muncul setelah 10 tahun menderita DM. ${ }^{15}$ Selain itu, penelitian Priyantono menyatakan bahwa faktor risiko signifikan untuk perkembangan neuropati diabetik berhubungan dengan usia, durasi menderita DM, hipertensi, dislipidemia, merokok, dan body mass index $(\mathrm{BMI}) .{ }^{16}$

\section{Hasil pemeriksaan monofilamen pada pasien Diabetes Melitus (DM) di poli klinik penyakit dalam RSUD Arifin Achmad Provinsi Riau}

Pada penelitian ini dilakukan pemeriksaan monofilamen pada 73 pasien DM tipe 2 dan didapatkan hasil bahwa kelompok pasien dengan skor 0-3 (Presence of neuropathy is likely) sebanyak 19 orang $(26 \%)$. Hasil tersebut menunjukkan angka yang cukup tinggi, bahwa ada sekitar 19 pasien dari 73 pasien yang sudah memiliki gejala neuropati. Skor 0-3 bermakna bahwa dari 8 titik yang diberikan stimulus monofilamen lalu dijumlahkan skor titik yang pasien dapat merasakan stimulus, maka didapatkan hasil skor 0-3. Hal tersebut menunjukkan bahwa sudah terjadi penurunan sensasi rasa pada kaki pasien. Hal ini dapat menjadi masalah besar jika tidak dilakukan pengelolaan yang tepat. Pasien dengan skor 0-3 dapat diberikan terapi neuropati dan direkomendasikan untuk melakukan pemeriksaan Elektromiografi (EMG).

Kelompok pasien dengan skor 3,5-5 (Risk of new onset neuropathy in next four years is high) 
yaitu 27 orang (37\%). Untuk pasien dengan skor 3,5-5 bermakna bahwa saat diberikan stimulus dengan monofilamen dan dijumlahkan skor semua titik yang pasien dapat merasakan sensasi didapatkanlah hasil 3,5-5. Hal tersebut kurang dari skor yang diharapkan yaitu 8 , artinya dapat merasakan semua sensasi yang diberikan pada semua titik. Untuk pasien dengan skor ini dapat diberikan edukasi dan melakukan kontrol glikemik yang ketat. Dari berbagai literatur menyatakan bahwa kontrol glikemik yang buruk dapat mempercepat progresifitas dari perkembangan neuropati diabetik. Selain mengontrol glikemik, pasien dapat melakukan perawatan umum/kaki seperti menjaga kebersihan kulit kaki, cegah trauma pada kaki untuk menurunkan risiko terjadinya ulkus pada kaki.

Pada pasien dengan skor $>5,5$ (Low risk of neuropathy onset in the next four years) sebanyak 27 orang (37\%). Hal ini berarti pasien memiliki risiko rendah untuk neuropati dalam 4 tahun kedepan, namun pasien ini harus tetap diperhatikan kontrol glikemiknya. Walaupun dengan skor $>5,5$ berarti ada pasien yang dapat merasakan semua titik atau mempunyai skor 8 , bukan berarti pasien tersebut bebas dari risiko neuropati. Hal ini harus menjadi perhatian untuk mencegah progresifitas neuropati meningkat.

Dengan hasil pemeriksaan neuropati yang sudah dilakukan di poliklinik penyakit dalam RSUD Arifin Achmad Provinsi Riau berarti populasi pasien DM yang datang sudah memiliki komplikasi. Seharusnya yang diharapkan itu adalah pasien dengan sensibilitas nilai 8 atau lebih. Maka dari itu, pemeriksaan monofilamen ini sangat penting untuk menskrining pasien DM untuk menurunkan risiko neuropati diabetik sehingga dapat mencegah ulkus diabetik pada kaki.

Pemeriksaan monofilamen dapat dilakukan untuk mendeteksi dini penurunan sensasi pada kaki sehingga meminimalkan risiko terjadinya ulkus kaki pada pasien DM. Pada penelitian ini, pemeriksaan monofilamen dilakukan pada pasien DM tipe 2 yang belum terdiagnosis neuropati diabetik dan memiliki ulkus. Hal ini dikarenakan pemeriksaan monofilamen pada penelitian ini dilakukan untuk mendeteksi lebih dini sehingga pasien yang memiliki risiko tinggi dapat direkomendasikan untuk melakukan pemeriksaan Elektromiografi(EMG).
Meskipun begitu, pemeriksaan EMG membutuhkan keahlian khusus, tidak praktis untuk penggunan sehari-hari, dan tidak semua rumah sakit memiliki EMG karena harganya relatif mahal. Berbagai penelitian telah dikembangkan untuk menemukan alat pemeriksaan untuk neuropati diabetis yang praktis digunakan sehari-hari, salah satunya monofilamen. Alat monofilamen ini sebaiknya digunakan maksimal 10 pasien/hari dan visko-elastisistasnya dapat pulih kembali setelah di istirahatkan 24 jam. Oleh karena itu, setiap fasilitas kesehatan direkomendasikan untuk memiliki beberapa alat monofilamen untuk memaksimalkan pemeriksaan. ${ }^{17}$

\section{SIMPULAN}

Karakteristik pasien perempuan lebih banyak dari pada pasien laki-laki yaitu sebanyak $44(60,3 \%)$, kelompok usia terbanyak yang berkunjung ke poliklinik penyakit dalam adalah 56 - 65 tahun yaitu sebanyak 38 orang $(52,1 \%)$, dan kelompok lama riwayat DM terbanyak adalah 5-10 tahun yaitu sebanyak 38 orang $(52,1 \%)$. Hasil pemeriksaan monofilamen menunjukkan semua pasien DM berisiko untuk neuropati diabetik, dengan hasil sebagai berikut: skor 0-3 (The presence of neuropathy is likely) sebanyak 19 orang (26\%), skor 3,5-5 (The risk of new onset neuropathy in the next four years is high) sebanyak 27 orang (37\%), skor $>5,5$ (Low risk of neuropathy onset in the next four years) sebanyak 27 orang (37\%).

\section{DAFTAR PUSTAKA}

1. International Diabetes Federation. IDF Atlas Seventh Edition. 2015

2. International Diabetes Federation. IDF Atlas Sixth Edition.2013

3. Jambat S, Ammache Z, Haddad F, et al. Prevalence of painful diabetic peripheral neuropathy among patients with diabetes mellitus in the Middle East Region. The Journal of International Medival Research. 2011; 39: $366-$ 377

4. Roza RL, Afriant R, Edward Z. Faktor risiko terjadinya ulkus diabetikum pada pasien diabetes 
mellitus yang dirawat jalan dan inap di RSUP Dr. M. Djamil dan RSI Ibnu Sina Padang. Jurnal Kesehatan Andalas. 2015; 4 (1): 243 - 8

5. Boulton AJ. The diabetic foot: from art to science. Diabetologia. 2004; 47: 1343 - 53

6. Nyamu PN, Otieno CF, Amayo CF, McLigeyo SO. Risk factors and prevalence of diabetic foot ulcers at Kenyatta National Hospital, Nairobi. East African Medical Journal. 2003; 80 (1): 36 43

7. Setyoko BA. Nilai diagnostik monofilamen $10-\mathrm{g}$ dan skor Clinical Neurological Examination (CNE) pada polineuropati diabetic [Tesis]. Universitas Diponegoro Semarang.2003

8. Irawan D. Prevalensi dan faktor risiko kejadian diabetes mellitus tipe 2 di daerah Urban Indonesia. (Analisa data sekunder RISKESDAS 2007).[Tesis]. Universitas Indonesia. 2010

9. Pardede TE. Gambaran pengendalian diabetes melitus berdasarkan parameter indeks massa tubuh dan tekanan darah di poli rawat jalan penyakit dalam RSUD Arifin Achmad. JOM FK. 2016

10. Nyoman SI. Pola konsumsi makanan tradisional Bali sebagai faktor risiko diabetes melitus tipe 2 di Tabanan. Jurnal Skala Husada.2009;6(1): 7581
11.Zahtamal, Chandra F, Suyanto, Restuastuti T. Faktor-faktor risiko pasien diabetes melitus. Berita Kedokteran Masyarakat. 2007; 23(3):142147

12.International Diabetes Federation. IDF Atlas Fifth Edition. 2015

13. Yuliani F, Oenzil F, Iryani D. Risiko hubungan berbagai faktor terhadap kejadian penyakit jantung koroner pada penderita diabetes melitus tipe 2. Jurnal Kesehatan Andalas. 2014;3(1):3740

14. Ramadhiati. Karakteristik penderita diabetes melitus tipe 2 dengan komplikasi kronik yang dirawat jalan bagian penyakit dalam RSUD Arifn Achmad Provinsi Riau periode 20032004.[Skripsi]. Pekanbaru. Fakultas Kedokteran Universitas Riau. 2006

15. Andatu RL. Hubungan antara durasi menderita Diabetes Melitus (DM) dengan angka kejadian neuropati diabetic. Naskah Publikasi. Universitas Muhammadiyah Yogyakarta. 2016

16.Priyantono T. Faktor -faktor risiko yang berpengaruh terhadap timbulnya polineuropati pada penderita diabetes melitus tipe 2. Semarang. Universitas Diponegoro. 2005

17.Amstrong DG. The 10-g monofilament the diagnostic driving rod for diabetic foot?. Diabetes Care J. 2000;23(7):887 